\title{
Simulating long-term soil redistribution generated by different patterns of mouldboard ploughing in landscapes of complex topography
}

\author{
S. De Alba \\ Universidad Complutense de Madrid(UCM), Facultad de CC, Geológicas Dpto. de Geodinámica, Ciudad Universitaria, 28040 Madrid, Spain
}

\begin{abstract}
In agricultural landscapes, translocation and redistribution of soil during tillage operations have been described as intense geomorphic, soil degradation and erosion (mechanical or tillage erosion) processes. This paper presents the design and calculation algorithms of the Soil Redistribution by Tillage (SORET) model. The SORET model is of the spatial distribution type and can perform 3D simulations of soil redistribution in Digital Terrain Models (DTMs) on the field scale. It can predict soil redistribution arising from different patterns of tillage in a given landscape via computer simulation of a single tillage operation, and is also able to forecast the long-term effects of repeated operations. Using the model, simulation was made of the long-term effects of three different patterns of tillage achieved using a mouldboard plough: (i) contouring, (ii) up-downslope, and (iii) downslope alone. The DTM selected was a field of complex topography and up to $40 \%$ slope with a Calcic Haploxeralf (Calcic Luvisol) soil in Central Spain. Results indicate substantial differences in the effects of the three tillage patterns in terms of absolute soil erosion-accumulation rates and the spatial distribution of areas of soil loss and deposition. These findings also suggest complex interaction between topography and direction of tillage, which ultimately determines the intensity and pattern of soil redistribution. Repeated downslope tillage gave rise to most intense soil degradation by tillage erosion, with an eroded area of $62 \%$ of the DTM, and an average erosion rate of $27.8 \mathrm{Mg} \mathrm{ha}^{-1}$ per tillage operation. For contouring tillage, the eroded area was $59 \%$ of the total DTM and the average erosion rate was $16.7 \mathrm{Mg} \mathrm{ha}^{-1}$ per tillage operation; for up-downslope tillage, these variables were $67 \%$ and $15.1 \mathrm{Mg} \mathrm{ha}^{-1}$, respectively. The SORET model appears to be a useful tool for simulating the spatial variability of soil redistribution and soil erosion-accumulation rates determined by different patterns of tillage in the long term. However, additional field data on the initial variability of soil properties are required if the effects of soil redistribution on soil degradation are to be adequately evaluated.
\end{abstract}

Keywords: Tillage erosion; Tillage translocation; Soil redistribution; SORET model; Mouldboard plough; Contouring; Central Spain

\section{Introduction}

Soil translocation and redistribution by the direct action of tillage have been identified as severe soil degradation processes of erosion (tillage erosion or mechanical erosion). Tillage erosion has been described as the major cause of physical soil degradation in rolling agricultural landscapes (e.g. Lindstrom et al., 1992; Quine et al., 1993; Govers et al., 1996, 1999; De Alba, 1998a). The long-term effects of soil redistribution by tillage have been reported to 
increase the variability of soil properties (Sibbensen and Andersen, 1985; Van Oost et al., 2000; Kosmas et al., 2001), transform soil profile morphology and landscapes (De Alba and Lindstrom, 2002), and lead to a significant decline in soil productivity (Schumacher et al., 1999). Further, the intensity of soil redistribution gives rise to substantial changes in surface hydrology and active geomorphic slope processes (e.g. Papendick and Miller, 1977; Dabney et al., 1999; Govers et al., 1999; Torri et al., 2002).

Tillage practices involving the use of the mouldboard plough require particular attention, since this implement moves an entire soil layer at a uniform depth, generally $24-40 \mathrm{~cm}$. The surface soil layer becomes inverted and displaced following an oblique angle to the path of the tractor, i.e. forward in the direction of tillage and laterally in a perpendicular direction to that of tillage.

The first documented experimental study in which soil translocation by tillage was evaluated dates back to the 1940s (Mech and Free, 1942). Since then, several field experiments have quantified the soil movement generated by different tillage implements by applying different research methods. Of particular interest are the works related to the use of the mouldboard plough of Lindstrom et al. (1990, 1992), Revel et al. (1993), Govers et al. (1994), Lobb et al. (1995), Van Muysen et al. (1999) and De Alba (1998a, 2001).

Lindstrom et al. (1990) developed the first model of soil translocation by tillage as a statistical relationship between soil displacement $(\boldsymbol{d})$ and slope gradient $(S)$ of the type $d=f(S)$. This relationship was later assessed under different experimental conditions (e.g. Govers et al., 1994; Lobb et al., 1995; Poesen et al., 1997; De Alba, 1998b). Govers et al. (1994) proposed modelling net downslope soil flux as a diffusion-type process, the intensity of which may be characterised by a single parameter, the diffusion coefficient. The diffusion coefficient represents net downslope displacement per unit slope after two tillage operations conducted in opposite directions. Thus, the use of the diffusion model is constrained by the assumption that tillage operations are performed in opposing directions at the same frequency. Only limited attempts have been made to simulate the long-term effects of soil redistribution by tillage on complex landscapes. Moreover, most of these efforts are based on the diffusion coefficient concept, which only considers the influence of the slope gradient in the direction of soil movement, either parallel or perpendicular to tillage. One of the most relevant models is the Tillage Erosion Prediction (TEP) model developed by Lindstrom et al. (2000), which can predict soil redistribution along single slope profiles. Van Oost and Govers (2000) developed the Water and Tillage Erosion Model (WATEM), which simulates 2D pattems of soil redistribution using a diffusion-type equation and assumes that all soil ranslocation occurs in the direction of steepest slope, irrespective of the pattern of tillage. On the other hand, Torri and Borselli (2002) and De Alba (2001) demonstrated that the asymmetric nature of soil movement produced by the mouldboard plough implies complex interaction between topography and direction of tillage, and that this interaction conditions the final intensity and pattern of soil redistribution.

This paper describes the algorithms and calculation procedures of the Soil Redistribution by Tillage (SORET) model. Some preliminary results of this model have been recently described by De Alba (1998a, 1999) and De Alba and Lindstrom (2000). The SORET model is of the spatially distributed type and simulates soil redistribution by tillage using Digital Terrain Models (DTMs) of individual fields. Computations are made using soil translocation models of the type $d=f(\mathrm{ST} ; \mathrm{SP})$, in which actual, forward and lateral translocations are calculated as functions of the slope gradients simultaneously in the directions: parallel (ST) and perpendicular to the direction of tillage (SP). Herein, the SORET model was used to compare the long-term effects on soil redistribution and spatial variability of soil-accumulation rates related to three different patterns of tillage (contouring, up-downslope, and repeated downslope tillage) in a field of complex topography. Also discussed is the influence of interaction between relief complexity and tillage pattern on the intensity of soil translocation and spatial variability of soil redistribution.

\section{Materials and methods}

\subsection{SORET model}

A general scheme of the SORET model is provided in Fig. 1. The simulation process is built around deterministic models based on the relationship between 


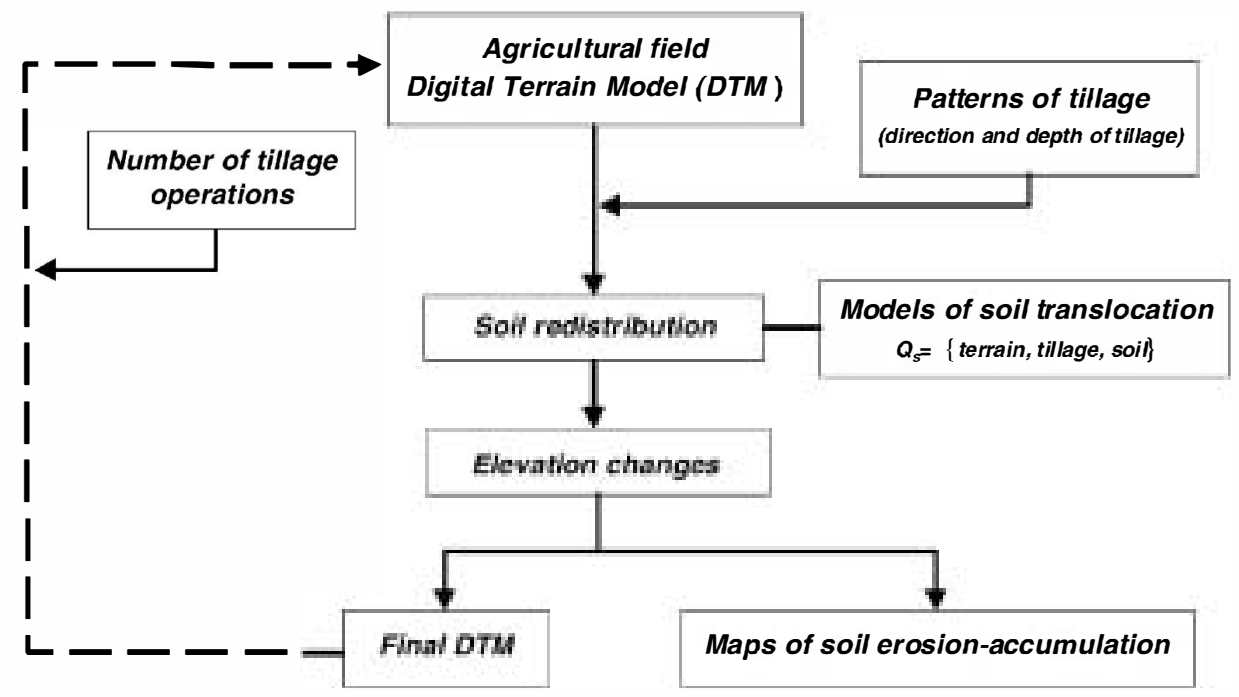

Fig. 1. General scheme of the SORET model. The SORET model is a spatially distributed model that performs 3D simulations of soil redistribution by tillage on DTMs on a field scale.

tillage translocation intensity and the properties of the terrain (i.e. slope gradients), tillage and soil (i.e. dry soil bulk density). Besides the DTM of the individual agricultural field, inputs for the simulation process include single or multiple patterns of tillage, as well as the total number of tillage operations to be simulated. As outputs, the model produces a final DTM of the field showing the topographical variations produced by tillage, a raster map showing absolute changes in the soil surface level (i.e. depth of soil loss or accumulation), and a map showing the spatial variability of average soil erosion-accumulation rates expressed as $\mathrm{Mg} \mathrm{ha}^{-1}$ per year. The simulation process involves a calculation step corresponding to a single tillage operation, after which a modified DTM is produced. The model can, therefore, predict soil redistribution effects of a single operation, as well as the long-term effects of repeated patterns of tillage. When more than one tillage operation is simulated, for each operation soil redistribution is always calculated using the DTM modified by previous operations. A detailed flowchart of the model is provided in Fig. 2.

\subsubsection{Patterns of tillage}

At the present development stage, the SORET model can simulate the soil redistribution effects of tillage using a right-hand mouldboard plough. As inputs, single or multiple patterns of tillage can be introduced indicating the direction/s, depth/s and frequency of tillage.

\subsubsection{DTM and slope gradients}

Since the soil redistribution process is simulated on the field scale, the resolution of the DTM should be as high as possible. However, to avoid problems of non-conservation of soil matter during computation, DTM resolution requires that cell sizes be larger than the maximum soil displacement possible by a single tillage operation. Considering the translocation models presented below (Eqs. (2) and (3)), a DTM resolution of cell size equal to or greater than $1 \mathrm{~m}$ should be used. In order to calculate the slope gradients ST and SP, the model uses the difference in elevation between adjacent cells according to the direction of tillage of each operation.

\subsubsection{Soil translocation models}

The SORET model is based on soil translocation models developed using data from field experiments performed in Central Spain (Toledo) in 1995/1996. In field experiments, in order to measure soil displacement by tillage, a modified version of the field method of Lindstrom et al. (1990) was used. The method involves the use of metallic tracers buried in the soil on 


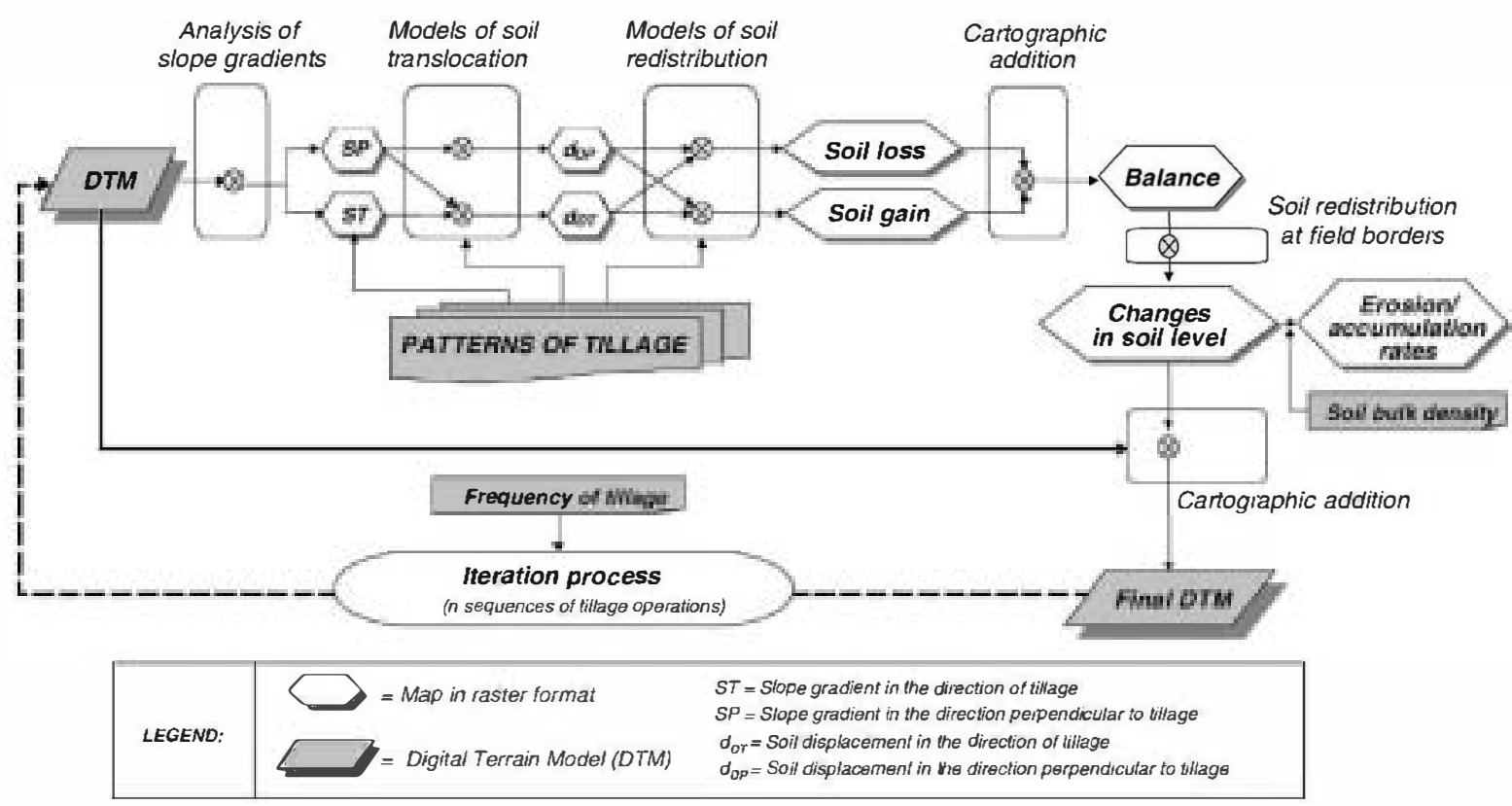

Fig. 2. Flowchart indicating the calculation procedures of the SORET model. The simulation process irrvolves a calculation step corresponding to a single tillage operation, after which a modified DTM is produced. The model can, therefore, predict soil redistribution effects of a single operation, as well as the long-term effects of repeated tillage operations.

a regular grid to measure soil translocation by comparing initial and final tracer positions after tilling. A detailed description of the experiments and results can be found in De Alba (2001).

The SORET soil translocation models are of the multivariate type $\boldsymbol{d}=f(\mathrm{ST} ; \mathrm{SP})$, in which the soil displacements actual, forward and perpendicular $(\boldsymbol{d}$, $d_{\mathrm{DT}}$, and $\boldsymbol{d}_{\mathrm{DP}}$, respectively) are calculated as functions of the slope gradients simultaneously in both directions, parallel (ST) and perpendicular to the direction of tillage (SP), as follows:

$d=\sqrt{d_{\mathrm{DT}}^{2}+d_{\mathrm{DP}}^{2}}$

$d_{\mathrm{DT}}=\frac{38.03-0.62 \mathrm{ST}+0.40 \mathrm{SP}}{100}$

$d_{\mathrm{DP}}=\frac{41.4-0.50 \mathrm{SP}}{100}$

where displacements $\boldsymbol{d}, \boldsymbol{d}_{\mathrm{DT}}$ and $\boldsymbol{d}_{\mathrm{DP}}$ are expressed in metres and slope gradients in percentages. According to the convention first adopted by Lindstrom et al. (1990), in Eqs. (2) and (3), negative signs are assigned to the ST slope when the tractor moves downwards, and to the SP slope when the lateral soil movement is downwards, while positive signs are assigned in the opposite cases. The model in Eq. (2) shows that soil translocation $\boldsymbol{d}_{\mathrm{DT}}$ is inversely correlated with the slope gradient in the direction of tillage ST and directly correlated with the slope gradient in the perpendicular direction SP. In contrast, lateral soil translocation $\boldsymbol{d}_{\mathrm{DP}}$ is only inversely correlated with the slope gradient SP.

\subsubsection{Models of soil redistribution}

Soil redistribution is calculated across cells in the DTM, considering a mobile window for a matrix of $3 \times 3$ cells (Fig. 3 ). For the central cell $(i, j)$, the SORET model calculates net soil translocation $Q_{\operatorname{sn}(i, j)}$ $\left(\mathrm{m}^{3}\right)$ as the balance between soil loss $L_{\mathrm{s}}(i, j)$ (Fig. 3a) and soil gain $G_{\mathrm{s}(i, j)}$ from neighbouring cells (Fig. 3b), according to the following equation:

$Q_{\mathrm{sn}(i, j)}=G_{\mathrm{s}(i, j)}-L_{\mathrm{s}(i, j)}$

where soil loss $L_{\mathrm{s}(i, j)}$ is given by

$$
\begin{aligned}
L_{\mathrm{S}(i, j)}= & {\left[\left(\boldsymbol{d}_{\mathrm{DT}(i, j)} L\right)+\left(\boldsymbol{d}_{\mathrm{DP}(i, j)} L\right)\right.} \\
& \left.-\left(\boldsymbol{d}_{\mathrm{DT}(i, j)} \boldsymbol{d}_{\mathrm{DP}(i, j)}\right)\right] D
\end{aligned}
$$




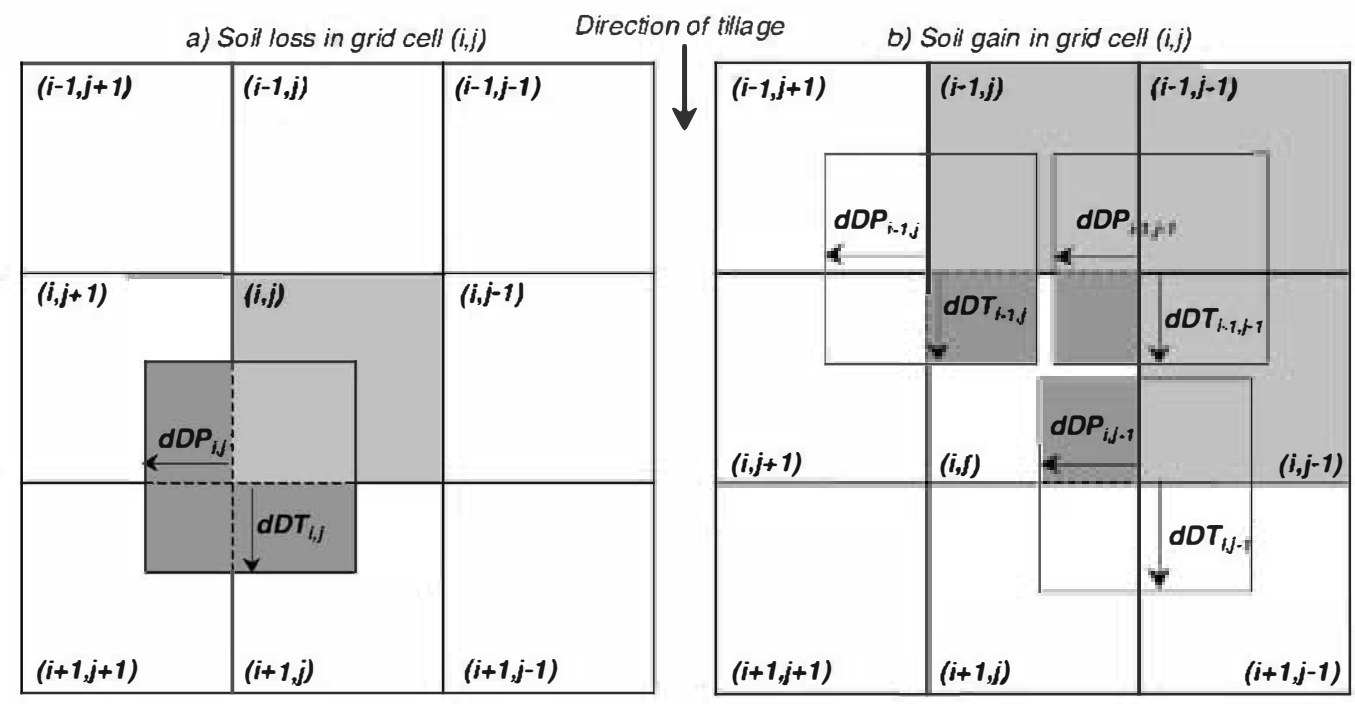

Fig. 3. Model of soil redistribution between adjacent cells in the DTM using a mobile window for a $3 \times 3$ cell matrix. This example shows the procedure used to calculate: (a) soil output from the central cell (i, j); (b) soil inputs from adjacent cells to the central one produced by a tillage operation conducted from top to bottom in the figure.

where $D$ is the depth of tillage $(\mathrm{m}), L$ the length of cell side, i.e. grid resolution $(\mathrm{m})$ and soil gain $G_{\mathrm{S}(i, j)}$ is calculated as follows:

$$
\begin{aligned}
& G_{\mathrm{S}(i, j)}=Q_{\mathrm{sfrom}(i-1, j)}+Q_{\mathrm{sfran}(i-1, j-1)} \\
& +Q_{\text {sfrom }(i, j-1)} \\
& Q_{\mathrm{sfrom}(i-1, j)}=\left[\boldsymbol{d}_{\mathrm{DT}(i-1, j)}\left(L-\boldsymbol{d}_{\mathrm{DP}(i-1, j)}\right)\right] D \\
& Q_{\mathrm{sfran}(i-1, j-1)}=\left(\boldsymbol{d}_{\mathrm{DT}(i-1, j-1)} \boldsymbol{d}_{\mathrm{DP}(i-1, j-1)}\right) D \\
& Q_{\mathrm{Sfrom}(i, j-1)}=\left[\boldsymbol{d}_{\mathrm{DP}(i, j-1)}\left(L-\boldsymbol{d}_{\mathrm{DT}(i, j-1)}\right)\right] D
\end{aligned}
$$

Soil redistribution by tillage is a process confined to each agricultural field, since no soil export occurs outside the field. Consequently, the final balance of soil loss and soil gain over the whole DTM has to be zero:

$\sum Q_{\mathrm{sn}(i, j)}=0$

\subsubsection{Soil redistribution at field borders}

Field boundaries require a particular model of soil redistribution. As tillage operations are not conducted through field boundaries, they act as lines of zero flux. As a consequence, while computing soil redistribution, the DTM cells near field boundaries either gain or lose a single amount of soil, which results in the formation of a linear pile or deep incision, respectively, along the boundary. This anomaly at the boundary can lead to significant modifications in local slope gradients and the simulating process becomes unstable after a few computation cycles. To avoid this effect, the model redistributes the total amount of soil that should be accumulated or lost in the last cell among a fixed number of adjacent cells in the same row or colunm perpendicularly aligned to the boundary. This secondary redistribution satisfies criteria of levelling the set of cells when going up or down, as shown graphically in Fig. 4. The latter is equivalent to simulating an idealised secondary tillage operation of levelling conducted parallel to the field boundaries. The number of cells used for simulating the levelling operation depends on the complexity of the terrain and DTM resolution. In the simulation presented below, a levelling operation $6 \mathrm{~m}$ in width (i.e. six cells of $1 \mathrm{~m}$ length each) was applied.

\subsubsection{Elevation changes and tillage erosion rates}

To obtain the final DTM showing the changes in topography, net soil translocation is calculated, assuming uniform soil loss or accumulation over the 

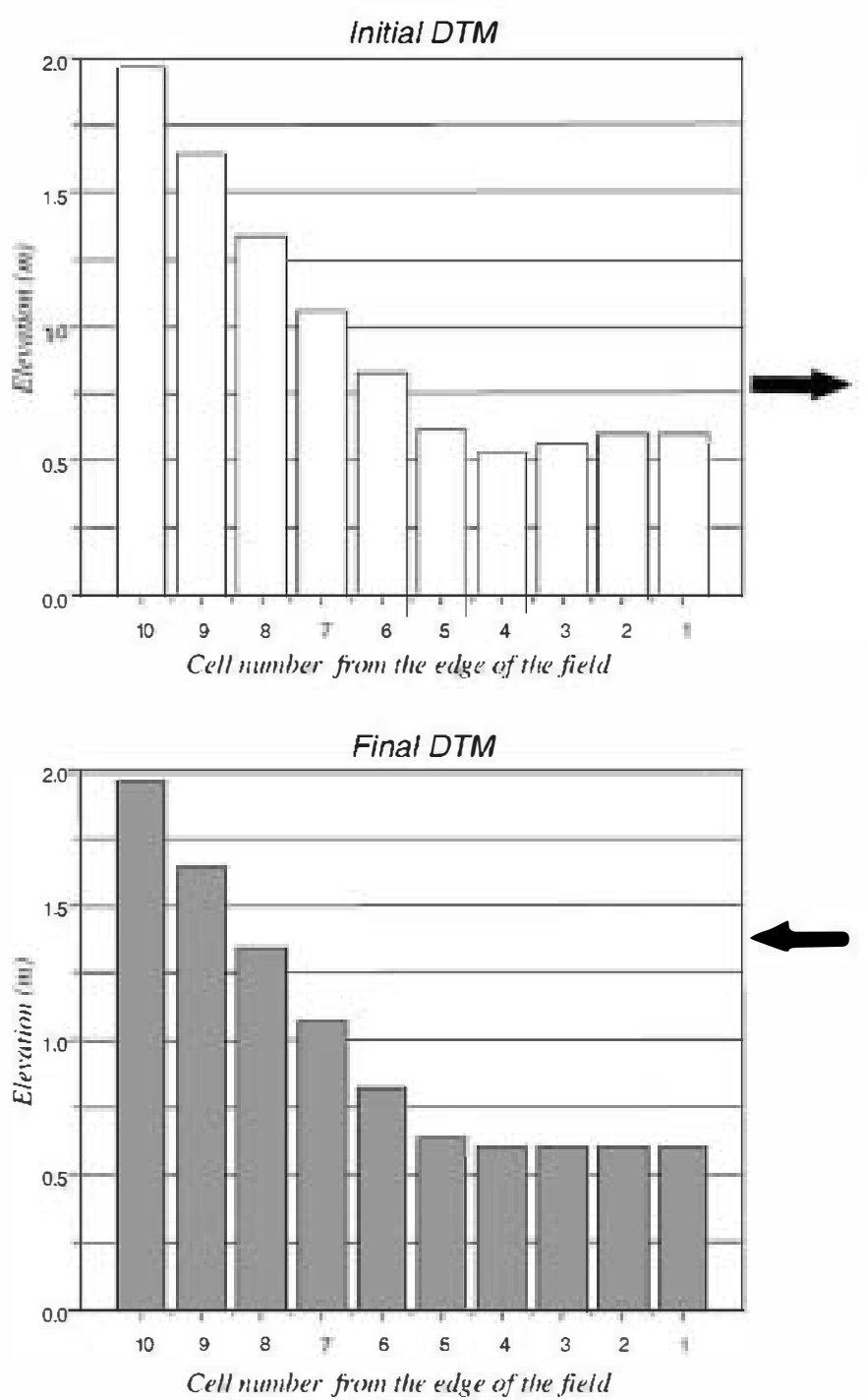

Estimated soi loss or gain for each grid cell
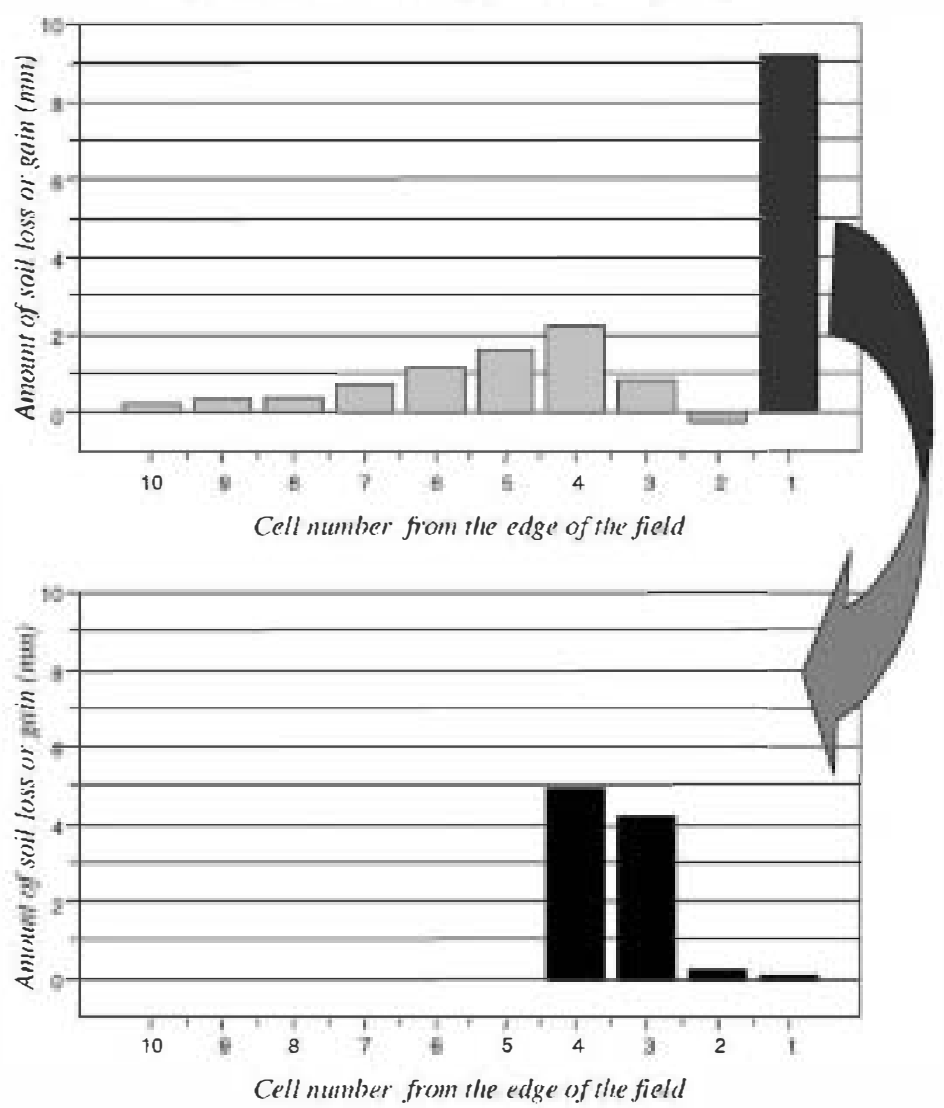

Cell number from the edge of the field

Fig. 4. Scheme of secondary soil redistribution applied to smooth the topography at the field borders after each simulated tillage operation. Accumulated soil at a boundary cell is distributed among adjacent cells (same DTM row or colunm perpendicularly aligned to the boundary), satisfying the criteria of levelling. 
entire area of each cell. Next, the final elevation change $\Delta z_{(i, j)}(\mathrm{m})$ is calculated according to

$$
\Delta z_{(i, j)}=\frac{Q_{\operatorname{sn}(i, j)}}{L^{2}}
$$

and the final erosion rate $T_{\mathrm{e}(i, j)}$ per operation of tillage $\left(\mathrm{Mg} \mathrm{ha}^{-1}\right)$ is estimated as

$T_{\mathrm{e}(i, j)}=\left(\frac{Q_{\mathrm{sn}(i, j)} \rho}{L^{2}}\right) \times 10$

where $\rho$ is the soil dry bulk density $\left(\mathrm{kg} / \mathrm{m}^{3}\right)$ and 10 is a unit conversion factor.

\subsection{Simulating the long-term effects of different patterns of tillage}

To predict the long-term effects of different tillage patterns on soil redistribution, three simulations were conducted using the DTM of an agricultural field of complex topography (Fig. 5). The field was located in La Higueruela Experimental Station (CSIC) in Central Spain (Toledo province). Climate is continental Mediterranean and average annual rainfall is around $450 \mathrm{~mm}$. The hillslope selected to perform the simulation analysis was north-facing. This field was given over to vine crops until ca. 1970 and later on mainly to herbaceous crops of cereals and sunflower (Helianthus sp.). The soil was a Calcic
Haploxeralf (Soil Survey Staff, 1990) and Calcic Luvisol (FAO, 1988). The topsoil (an Ocric horizon, $25-30 \mathrm{~cm}$ depth) was sandy-loam $\left(626 \mathrm{~g} \mathrm{~kg}^{-1}\right.$ sand, $188 \mathrm{~g} \mathrm{~kg}^{-1}$ silt, $186 \mathrm{~g} \mathrm{~kg}^{-1}$ clay) of average dry bulk density $1.37 \mathrm{~g} \mathrm{~kg}^{-1}$ and a low organic carbon content $\left(7.4 \mathrm{~g} \mathrm{~kg}^{-1}\right)$.

The DTM corresponds to an area of $6642 \mathrm{~m}^{2}$ and average and maximum slope gradients of 17 and $40 \%$, respectively; maximum elevation change is $13 \mathrm{~m}$. The slope is of a northern aspect and a generally convex profile with basal concavity, and also has two intermediate depressions lying in a north-south direction. To produce the DTM, a topographic survey of the field was conducted on a $5 \mathrm{~m} \times 5 \mathrm{~m}$ grid using a SOKKIA total station. The DTM was generated at a pixel resolution of $1 \mathrm{~m}^{2}(1 \mathrm{~m} \times 1 \mathrm{~m})$ and a final size of 123 columns $\times 54$ rows using a Kriging method of interpolation.

Three patterns of tillage corresponding to the use of a right-hand mouldboard plough were simulated: (a) contouring tillage alternating opposite directions; (b) tillage along the line of steepest slope alternating up-downslope directions; (c) repeated downslope tillage (Table 1). Table 1 shows the directions, frequency and depth of tillage for each pattern. To simulate tillage patterns as realistically as possible, it was assumed that the tillage directions up-down and contouring are related to the general slope directions in the DTM and not to local slopes between neighbouring

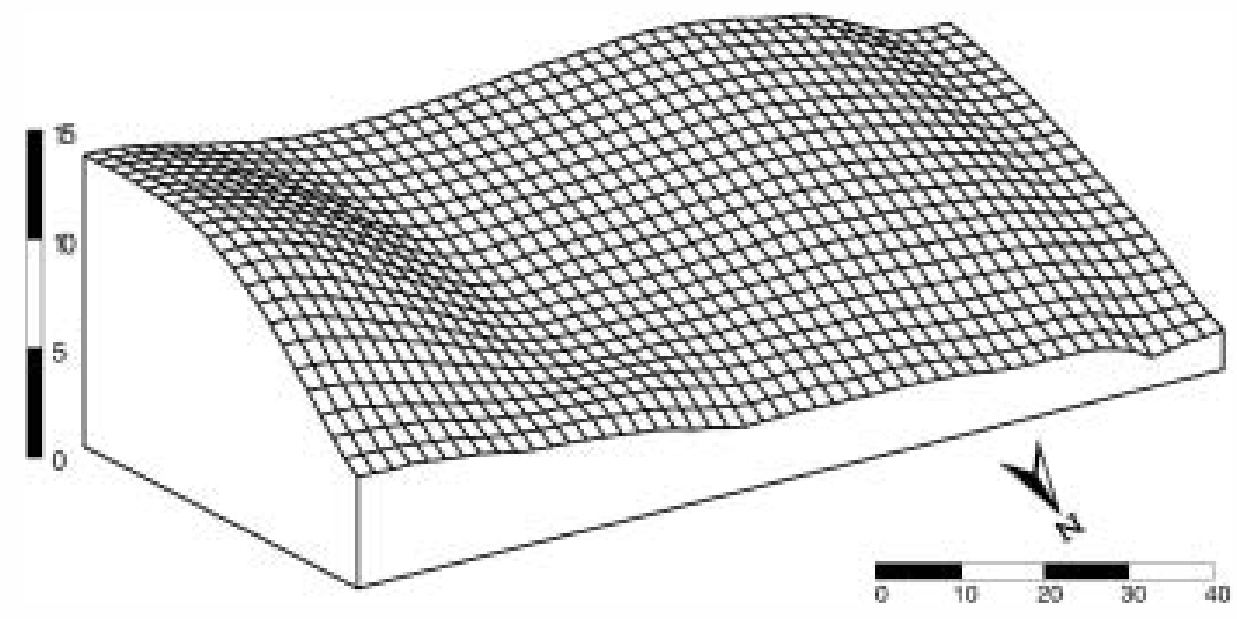

Fig. 5. Digital terrain model of the agricultural field used for simulating the long-term effects of soil redistribution by tillage. The DTM resolution is $1 \mathrm{~m}$ length (123 columns $\times 54$ rows). The field area is $6642 \mathrm{~m}^{2}$ and average and maximum slope gradients are 17 and $40 \%$, respectively. Horizontal and vertical scales are expressed in metres. 
Table 1

Tillage pattems used to simulate long-term effects on soil redistribution

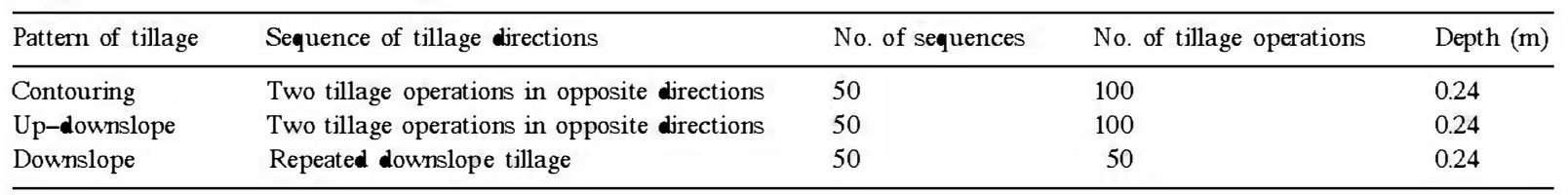

cells. For the DTM in Fig. 5, it is assumed that tillage up-downslope and contouring paths run parallel to the DTM columns and rows, respectively.

\section{Results and discussion}

\subsection{Spatial patterns of soil redistribution}

Fig. 6 shows simulation maps of soil redistribution after 50 tillage sequences. According to the pattem of tillage, considerably different effects were shown in terms of both absolute values of soil loss or gain, and the spatial variability of soil redistribution.

Table 2 provides a sununary of changes in surface level and rates of soil erosion and soil gain for the three tillage patterns. It should be noted that for the repeated downslope tillage pattern, results correspond to a total of 50 tillage operations (i.e. 50 tillage sequences of a single downslope operation), while for the other two tillage pattems, simulations represent a total of 100 tillage operations (i.e. 50 tillage sequences of two operations in opposite directions).

For the three tillage pattems, results show rates of tillage erosion several times higher than that considered sustainable for crop production in the study area (De Alba, 1998a). As expected, repeated downslope tillage was associated with the highest rates of soil translocation and erosion (Fig. 6c). For this tillage pattem, the SORET model predicted a $62 \%$ field area presenting net soil loss, average and maximum surface lowering values of 0.25 and $1.8 \mathrm{~m}$, respectively, and an average erosion rate of $67.7 \mathrm{Mg} \mathrm{ha}^{-1}$ per tillage operation. Similarly, the area of net soil gain (38\% field area) presented soil deposits of average and maximum depths of 0.40 and up to $2.9 \mathrm{~m}$, respectively.

In contrast, no clear differences were noted between results obtained for the tillage patterns contouring and up-downslope. Up-downslope tillage generated a greater area of net soil loss of 67 versus $59 \%$ for contouring tillage. However, within the eroded area, the intensity of soil loss was greater in the case of

Table 2

Sumunary of statistical analysis of surface elevation changes and erosion-accumulation rates for the different pattems of tillage ${ }^{a}$

\begin{tabular}{|c|c|c|c|}
\hline & \multicolumn{3}{|c|}{ Pattem of tillage } \\
\hline Total area of net soil loss & & & \\
\hline Total area $\left(\mathrm{m}^{2}\right)$ & $3892(59 \%)$ & $4435(67 \%)$ & $4106(62 \%)$ \\
\hline Mean elevation change (m) & -0.12 & -0.11 & -0.25 \\
\hline Maximum elevation change $(\mathrm{m})$ & -0.50 & -0.46 & -1.77 \\
\hline \multicolumn{4}{|l|}{ Total area of net soil accumulation } \\
\hline Total area $\left(\mathrm{m}^{2}\right)$ & $2750(41 \%)$ & $2207(33 \%)$ & $2536(38 \%)$ \\
\hline Mean elevation charıge $(\mathrm{m})$ & 0.17 & 0.22 & 0.40 \\
\hline Maximum elevation change $(\mathrm{m})$ & 1.16 & 1.39 & 2.92 \\
\hline Average soil gain (Mg per tillage operation) & 6.5 & 6.7 & 27.8 \\
\hline
\end{tabular}

${ }^{\mathrm{a}} \mathrm{A}$ soil dry bulk density of $1370 \mathrm{kgm}^{-3}$ was used to calculate erosion-accumulation rates. 
(a)

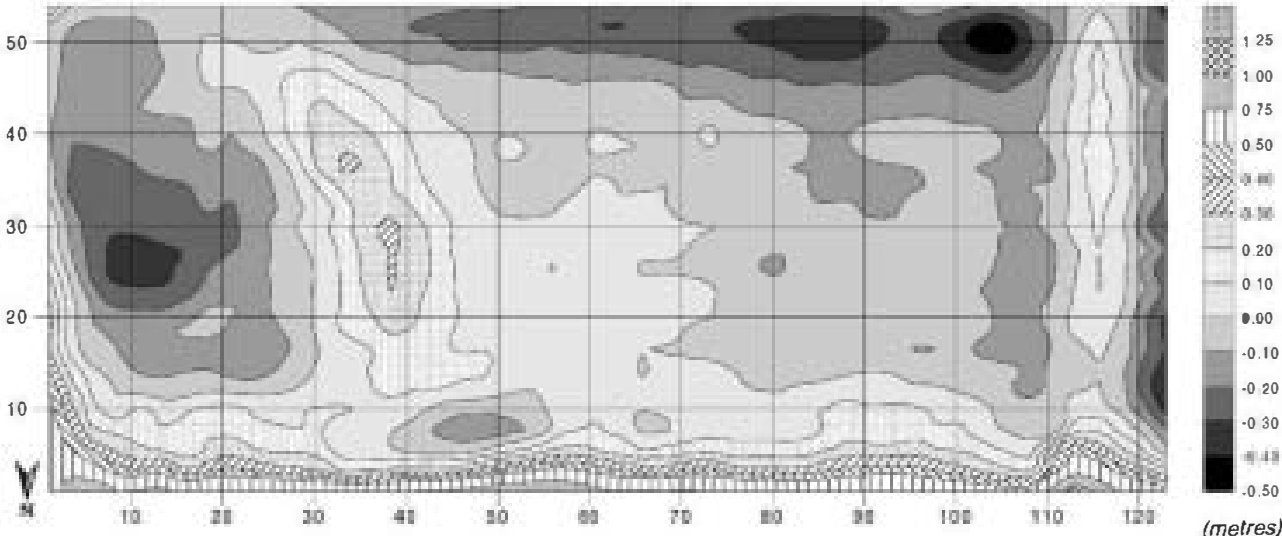

(b)
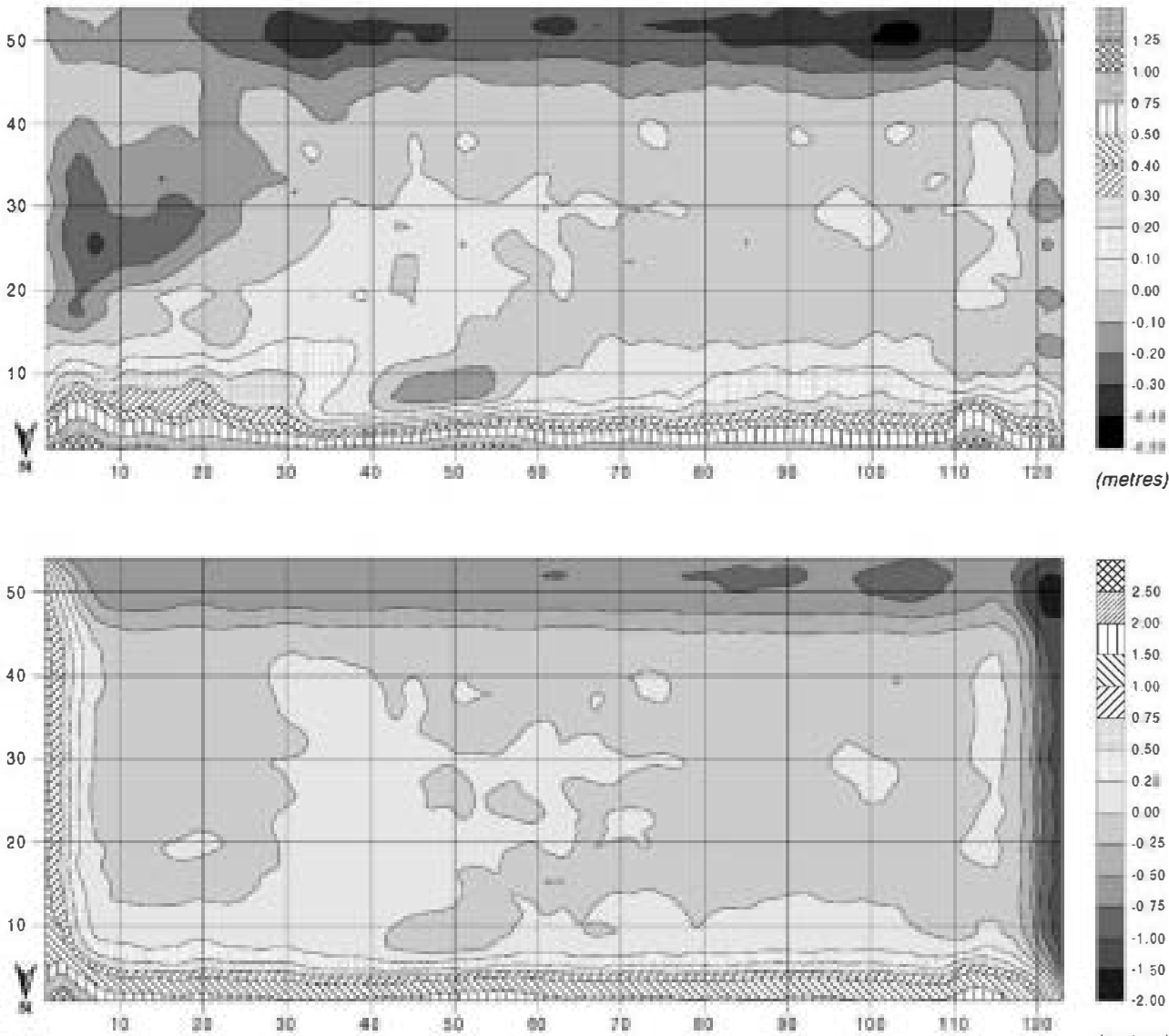

(c)

Fig. 6. Simulation maps of elevation changes after 50 tillage operation sequences for the three patterns of tillage: (a) contour tillage; (b) up-downslope tillage; (c) repeated downslope tillage (see Table 1) on the DTM in Fig. 5. 


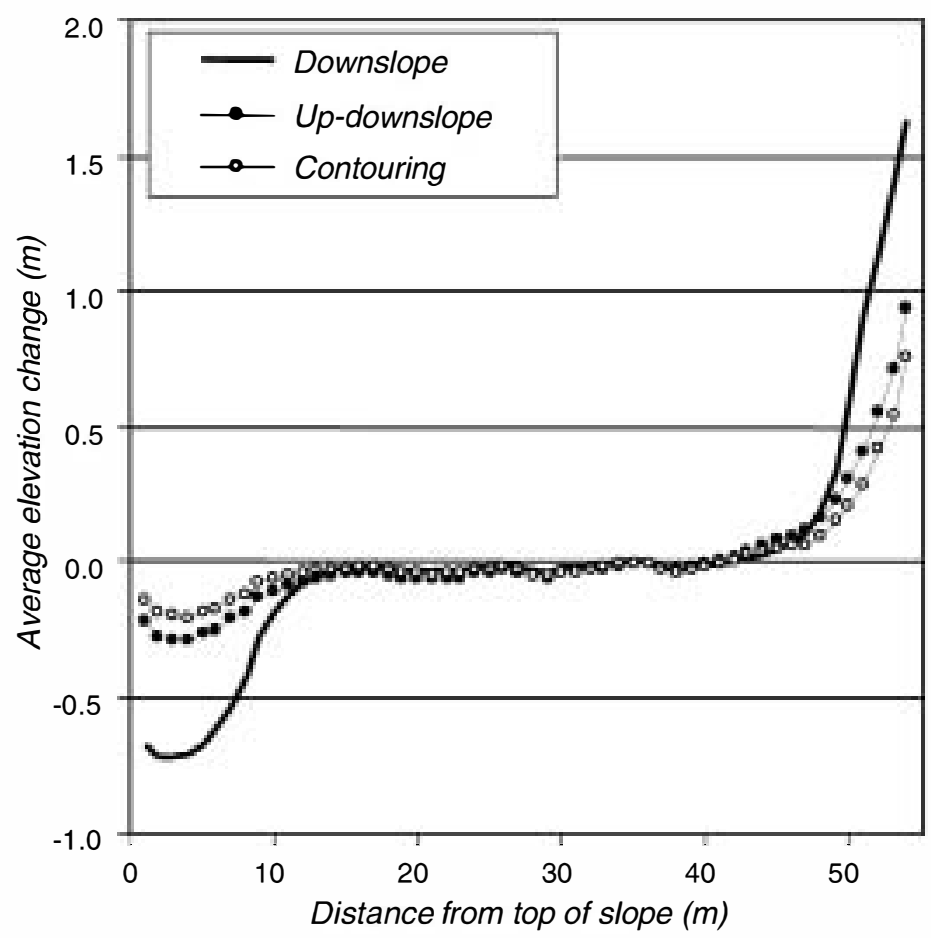

Fig. 7. Average elevation change along the longitudinal profile of the DTM (Fig. 4) after simulating 50 tillage sequences for the patterns of tillage described in Table 1. The curves represent average elevation change values for each DTM-row located at a distance $x$ from the top of the slope (see Eq. (13) in the text).

contouring tillage, average and maximum surface lowering being 0.12 and $0.50 \mathrm{~m}$, respectively, and the average soil erosion rate $16.7 \mathrm{Mg} \mathrm{ha}^{-1}$ per tillage operation. In comparison, up-downslope tillage gave rise to average and maximum surface lowering values of 0.11 and $0.46 \mathrm{~m}$, respectively, and an average soil erosion rate of $15.1 \mathrm{Mg} \mathrm{ha}^{-1}$ per tillage operation. However, due to the greater eroded area related to up-downslope tillage, a slightly higher total soil loss value was obtained; $6.7 \mathrm{Mg}$ per tillage operation versus $6.5 \mathrm{Mg}$ for contouring tillage.

\subsection{Average elevation changes}

Spatial patterns of soil redistribution in the simulation maps shown in Fig. 6 indicate a common tendency: substantial net soil loss in the upper part of the field and net accumulation at lower positions. Fig. 7 shows the average elevation change along the longitudinal profile of the DTM for the three patterns of tillage, calculated from

$\Delta z_{(i)}=\frac{\sum^{j=m} \Delta z_{(i, j)}}{m}$

where $\Delta z_{(i)}$ is the average elevation change $(\mathrm{cm})$ for the DTM row $i, \Delta z_{(i, j)}$ is the elevation change in the cell $(i, j)$, and $m$ is the total number of columns in the DTM. Average values show that the area of significant net soil loss was restricted to the upper slope sector, which is $12 \mathrm{~m}$ long and of convex morphology; while significant net soil accumulation occurred in the $10 \mathrm{~m}$ long, concave lower sector. In contrast, the intermediate sector, $12-40 \mathrm{~m}$ from the top and of predominant rectilinear morphology, was practically devoid of elevation changes.

\subsection{Average rates of downslope soil transport}

The average rate of net downslope soil transport per unit width $Q_{\mathrm{st}(k)}\left(\mathrm{kg} \mathrm{m}^{-1}\right.$ per tillage operation) 
in a given DTM-row located at a distance $x$ from the top of the slope, can be calculated as the total net soil loss that occurs in the area located upslope from this row to the top of the slope, divided by the total width $(\mathrm{Lm})$ of the DTM and the number $(n)$ of tillage operations simulated, using the following equation:

$$
Q_{\mathrm{st}(k)}=\frac{\sum^{i=k} \sum^{j=m} \Delta z_{(i, j)} \rho}{L m n}
$$

where $Q_{\mathrm{st}(k)}$ is the average rate of net soil transport through the DTM-row $k, \Delta z_{(i, j)}$ the net elevation change $(\mathrm{cm})$ in the grid-cell $(i, j)$, and $\rho$ the soil dry bulk density $\left(\mathrm{kg} / \mathrm{m}^{3}\right)$. Fig. 8 shows the variation in $Q_{\text {st }}$ along the longitudinal profile of the DTM. Comparing Figs. 7 and 8, it can be seen that highest soil transport rates corresponded to the intermediate slope sector, where most discrete surface level changes occur simultaneously. Consequently, this slope sector suffered the intense replacement of surface soil material with soil from upper slope positions. In contrast, in the lowest DTM-row, net soil transport was zero, indicating that all the soil removed was deposited within field boundaries, with no soil transport to the outside. Similar patterns of soil redistribution have been reported by several authors who simulated tillage translocation along single slope profiles of different levels of morphological complexity (e.g. Lindstrom et al., 1992; Govers et al., 1994; De Alba, 1998b), and modelling patterns of soil erosion on agricultural fields using caesium-137 spatial distribution data (Quine et al., 1993; Lobb et al., 1995).

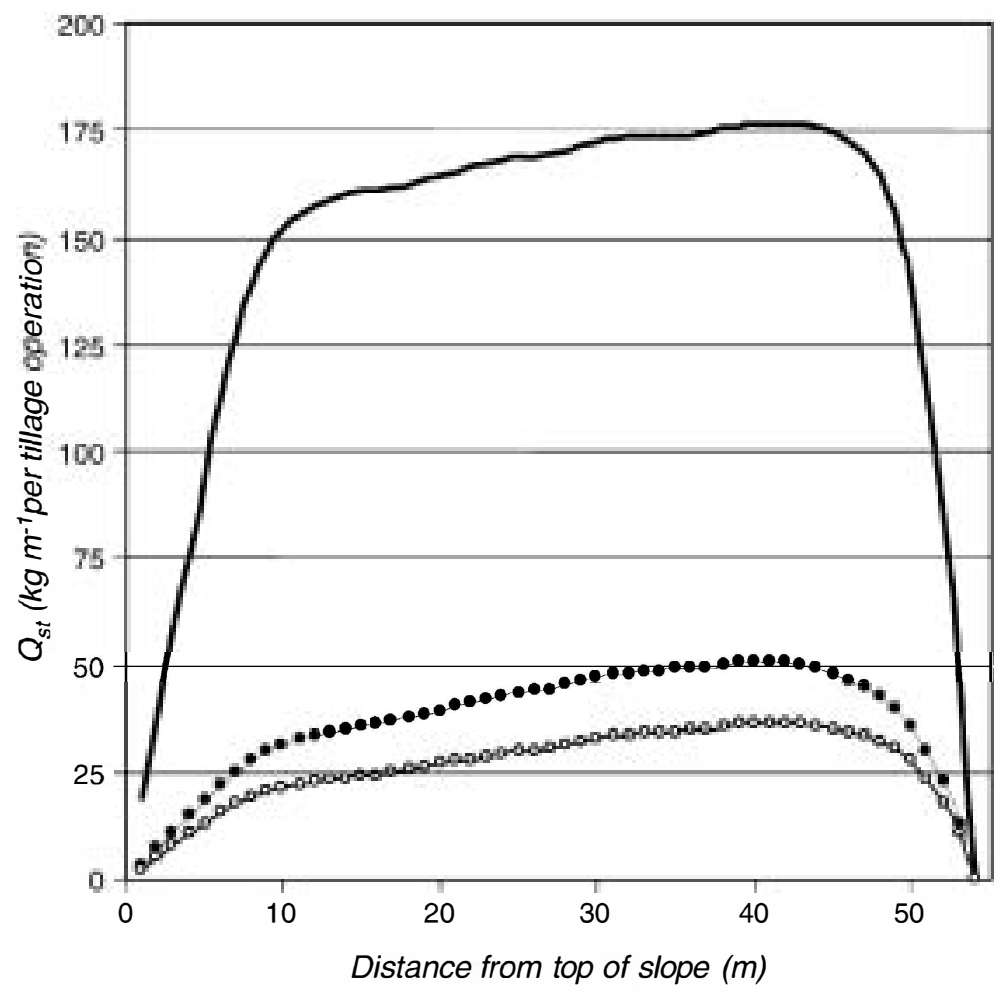

\section{Downslope $\longrightarrow$ Up-downslope $\longrightarrow$ Contouring}

Fig. 8. Variation of the average rate of net downslope soil transport along the longitudinal profile of the DTM after simulating 50 tillage sequences for the patterns of tillage described in Table 1 . The curves represent average values of $Q_{\text {st }}$ for each DTM-row located at a distance $x$ from the top of the slope (see Eq. (14) in the text). 


\subsection{Soil redistribution at field borders}

The simulation results showed that field boundaries play an important role in determining the spatial patterns of soil redistribution at border zones. Since field boundaries represent real physical barriers, which interrupt tillage and consequently soil transport flux, sources of uncertainty arise when modelling tillage translocation near the field boundary.

The SORET model makes use of an idealised secondary tillage operation of levelling to reproduce a smoothing effect at field boundaries. This secondary operation is needed to stabilise the iterative simulation process, but also has a physical meaning related to the common pattems of tillage in the study area. In real field conditions, after each primary tillage operation with the mouldboard plough, linear structures (pile or deep incision) appear along the field boundaries. However, these structures disappear during later operations of secondary tilling and crop sowing, such that the next mouldboard operation is performed on a newly smoothed surface (field observations).

An additional source of uncertainty at field borders derives from the fact that when tillage is conducted in a direction perpendicular to the boundaries (i.e. upper and lower boundaries when tillage is up- and downslope, and lateral boundaries when tillage is contouring), the tractor always has to change course when it reaches the boundary. This means that areas closest to the boundary are left unploughed. Moreover, parallel to the boundary, there is a strip in which tillage speed and depth are much reduced because the ractor has only just started to plough. In this marginal strip, soil translocation would thus be expected to be significantly reduced due to the effects of a slower tillage speed and shallower tillage depth, as has been empirically shown by Van Muysen et al. (2002). Nevertheless, it has been observed that the border area is commonly tilled at a higher intensity than the rest of the field, and that this intensity is commonly higher the smaller the field size (field observation). Farmers tend to apply a second, or even a third, tillage operation parallel to the field border, to avoid reducing the effective crop area at the border, and to render uniform the characteristics of the sowing-bed over the entire field. On the other hand, these additional tillage operations are rather variable and include several unknown factors such as the type of tillage implements used, tillage direction and total number of operations. A further unpredictable factor is that derived from the so-called "free will" of the tractor driver (Borselli et al., 2003).

The considerations above all point to the difficulty of setting up a model that can take into account such a large number of uncertain factors, as well as their possible interactions. A more profitable approach might be one such as that used in the SORET model, which consists of applying a simple model of secondary soil redistribution at the field borders for each simulated tillage operation, once the redistribution of soil due to the primary tillage pass has been calculated over the entire DTM (Fig. 2). In the present simulation analysis, it was assumed that soil translocation due to mouldboard ploughing was the same for all the grid cells as described in Eqs. (2) and (3). After calculating the modified DTM including the elevation changes, a secondary redistribution model is then applied to the field borders as described in Fig. 4.

For more accurate predictions, the secondary redistribution model would require specific calibration for the local agricultural conditions in which the model is used. A first attempt to calibrate the SORET model to take into account local agricultural conditions was made by Borselli et al. (2003) who used field data obtained by surveying dateable field features of soil redistribution by tillage in the Tuscany region (Central Italy). These authors compared the predictions of soil elevation changes by calibrated and uncalibrated versions of the SORET model after 100 tillage operations performed on a hillslope with a mid-slope boundary between two adjacent fields. Results indicated that the model predicts similar patterns of soil redistribution, while the uncalibrated version always yielded lower rates of elevation change, e.g. a difference of ca. $11 \%$ was obtained for the height of the bank formed at the mid-slope boundary between the two fields.

Unfortunately, there was insufficient current field data for the Central Spanish region for reliable calibration of the secondary redistribution model, thus further work is needed to survey dateable features of tillage erosion. On the other hand, since the aims of this analysis were to compare the spatial pattem of soil redistribution produced by different pattems of tillage and to obtain a preliminary estimate, albeit rough, of the elevation changes produced, accurate model calibration was not considered a major necessity. 


\subsection{Interaction between patterns of tillage and topography}

The soil redistribution maps shown in Fig. 6 point to significant effects of tillage pattems on the spatial variation of soil redistribution in landscapes of complex morphology when a 3D analysis is performed. When these maps are compared, opposite results are observed for the two intermediate depressions lying parallel to the longitudinal profile of the DTM (Fig. 4). While contouring tillage leads to net soil accumulation at both depressions, up-downslope operations give rise to a predominant net soil loss, and repeated downslope tillage provokes an intermediate response. These results indicate that profile morphology in a direction parallel to tillage plays a key role in the final balance of soil translocation. It is also of note that the simulation map of soil redistribution associated with repeated downs lope tillage (Fig. 6c), more clearly reflects the basic pattem of soil movement produced by a right-hand mouldboard plough, i.e. forward (downslope) and laterally to the right. This suggests that the simpler the pattern of tillage, the lower the impact of topography on the spatial soil redistribution pattern generated by mouldboard ploughing. Hence, the spatial variability of soil redistribution is determined by complex interaction between topography and the pattern of tillage. This interaction may be attributed to the asymmetric nature of soil movement by the mouldboard plough, as previously described by De Alba (2001) and Torri and Borselli (2002).

\subsection{Implications in modelling}

Findings suggest that because of the complex interaction between topography and the tillage pattern, soil translocation models, such as the so-called diffusion-type models (e.g. Govers et al., 1994, 1999; De Alba, 1998b), are inappropriate for characterising the soil redistribution due to mouldboard tillage in landscapes of complex topography (i.e. real reliefs).

Govers et al. (1994) proposed modelling soil ranslocation by tillage as a diffusion-type geomorphological process similar to rainsplash and soil creep. These authors called the proportionality coefficient, relating net unit soil transport rate $Q_{\text {snet }}$ $\left(\mathrm{kgm}^{-1}\right.$ per tillage operation) to the slope gradient $S\left(\mathrm{~m} \mathrm{~m}^{-1}\right)$, the diffusion constant or ransport coeffi- cient $K\left(\mathrm{kgm}^{-1}\right.$ per tillage operation). Thus, the main equation describing the process is

$Q_{\text {s net }}=k S$

In effect, the ransport rate $Q_{\text {s net }}$ corresponds to the average net downslope transport of soil (per unit width of slope and tillage operation) after two operations of tillage conducted in opposite directions, i.e. up- and downslope tillage or up- and downslope tuming of soil during contouring. Hence, $Q_{\text {s net }}$ can be calculated as the product of the difference between soil displacement $\boldsymbol{d}(\mathrm{m})$ due to the two opposite tillage operations, and average depth of tillage $D(\mathrm{~m})$ and soil dry bulk density $\rho\left(\mathrm{kg} \mathrm{m}^{-3}\right)$, as

$Q_{\text {snet }}=\frac{1}{2}\left(\boldsymbol{d}_{\text {up }}-\boldsymbol{d}_{\text {down }}\right) D \rho$

Using linear equations of the type $d=f(S)$ and considering the slope gradient $S$ defined as negative by Lindstrom et al. (1990), when tillage is downslope (or soil is tumed downslope during contouring tillage), $Q_{\text {s net }}$ can be calculated as

$Q_{\text {snet }}=\frac{1}{2}[(\boldsymbol{a}+b S)-(\boldsymbol{a}-b S)] D \rho=b S D \rho$

Finally, comparing Eqs. (15) and (17), the coefficient $k$ is given by

$k=-D \rho b$

As a consequence, this approach is constrained to the assumption that tillage is carried out in opposite directions (i.e. up- and downslope tillage or up- and downslope turning of soil during contouring tillage) equally as often. This necessary assumption excludes the possibility of simulating the effect of other tillage pattems, as is the case of the repeated downslope tillage simulated above using the SORET model.

On the other hand, the concept of the transport coefficient $k$ being a constant value, implies the need to use simple soil ranslocation models of the type $d=$ $f(S)$, in which soil displacement $\boldsymbol{d}$ is affected only by the slope gradient in the same direction as that of the soil movement considered. Nevertheless, soil translocation by mouldboard ploughing is strongly affected by the complexity of relief, and consequently by the slope gradient simultaneously in both directions, parallel ST and perpendicular SP to the direction of tillage (see Eqs. (1) and (2)).

Simulation models of soil redistribution based on diffusion-type equations that assume that all soil 
translocation occurs in the direction of the steepest slope (e.g. see Lobb and Kachanoski, 1999; Van Oost and Govers, 2000), are additionally constrained by the need to consider a fixed tillage direction parallel to the line of maximum local slope (i.e. local aspect) for each point in the DTM. However, this direction of tillage does not correspond to any possible pattern of tillage conducted over landscapes of a topography more complex than a simple plane, as in the case of real topography (e.g. the DTM in Fig. 5).

Moreover, De Alba (2001) and Torri and Borselli (2002) were independently able to demonstrate that highest values of downslope soil displacement during mouldboard ploughing are not attained when tillage is conducted along the direction of maximum slope gradient. These authors calculated a tillage direction of ca. $60^{\circ}$ (i.e. the angle between aspect and tillage direction) producing maximum soil translocation downslope using a right-hand mouldboard plough. This corresponds to a tillage operation conducted downslope (in a direction of angle $60^{\circ}$ ) and tuming of soil downslope. Further, De Alba (2001) found that in ca. $57 \%$ of all possible tillage directions in a plane of $15 \%$ slope, soil displacement is greater in the lateral direction $\left(\boldsymbol{d}_{\mathrm{DP}}\right)$ than in that of tillage $\left(\boldsymbol{d}_{\mathrm{DT}}\right)$.

According to the above, the SORET model calculates the actual soil translocation trajectory, as the resultant of the two orthogonal components of soil movement, $\boldsymbol{d}_{\mathrm{DT}}$ and $\boldsymbol{d}_{\mathrm{DP}}$, to simulate soil redistribution among the grid cells (Fig. 2).

\subsection{Soil degradation effects}

The simulation results show that the three patterns of tillage provoke extremely elevated local erosion rates, with highest values for the pattern of repeated tillage downslope. In all cases, maximum erosion rates are significantly greater than values considered as the maximum soil loss tolerable in conditions ideal for soil formation (see review in Schmidt et al., 1982).

Nevertheless, in terms of soil degradation consequences in the selected DTM, the absolute values of soil translocation and spatial patterns of soil redistribution obtained do not reflect which of the tillage pattems, up- and downslope or contouring, lead to greatest negative effects. Hence, the general assumption that contouring reduces tillage erosion (e.g. Lane, 1997) should be questioned, at least when consid- ering mouldboard tillage in landscapes of complex topography.

For a better evaluation of the risk of tillage erosion in a given landscape, one would need to undertake a comprehensive analysis, in which-along with the DTM and tillage pattem alternatives-detailed information on the spatial variability of soil properties was also taken into account. Sibbensen and Andersen (1985) demonstrated the significance of mixing and dispersion of soil constituents and developed a model to predict the cumulative effects of soil dispersion in long-duration field experiments involving small plots. More recent modelling approaches of soil dispersion due to tillage are those of Lobb and Kachanoski (1999) and Van Oost et al. (2000). At a slope scale, De Alba and Lindstrom (2002) proposed a conceptual2D model of soil catena modification, arising from soil profiles altered by the redistribution of soil material through the plough layer in agricultural landscapes. Through a case study, these authors documented field evidence of such a soil catena modification model and discussed the implications of the derived increase in soil variability on soil surveying and the practical applications of soil maps. In addition, it has been reported that soil redistribution due to tillage can provoke a significant increase in the spatial variability of the crop production potential (Schumacher et al., 1999; Kosmas et al., 2001).

\section{Conclusions}

The present results point to intense soil redistribution by tillage and highlight the role played by tillage as an important transformation mechanism of the agricultural landscape. Substantial differences were observed in the effects of the three tillage pattems simulated, in terms of absolute rates of soil erosion-accumulation and the spatial variability of areas of net soil loss and deposition. Repeated downslope tillage was associated with most intense soil degradation, yet the soil redistribution results obtained for contouring and up-downslope tillage, did not serve to predict the tillage pattem leading to most soil degradation. Up-downslope tillage gives rise to a more extensive eroded area than contouring tillage (67 versus 59\% field area, respectively), but the latter leads to a higher average erosion rate (16.7 versus 
$15.1 \mathrm{Mgha}^{-1}$ per tillage operation, respectively). This questions the general assumption that contouring reduces tillage erosion, at least when considering landscapes of complex topography. Results also point to complex interaction between topography and direction of tillage, which ultimately determines the intensity and pattern of soil redistribution.

These findings highlight the potential of the SORET model for predictive analyses aimed at evaluating the long-term effects on soil redistribution of different management practices or understanding present geomorphologic and soil landscapes. However, it would appear that the correct evaluation of the effects of soil redistribution on soil degradation and loss of soil quality requires detailed field data on the spatial variability of soil properties.

\section{Acknowledgements}

This study was financed by the Castilla-La Mancha Community Govemment (Spain) and a Marie Curie Fellowship of the European Community programme "Improving Human Research Potential" under contract no. HPMFCT-2000-00706.

\section{References}

Borselli, L., Pellegrini, S., Torri, D., De Alba, S., 2003. New methodologies for field measurements of tillage erosion, (submitte for publication).

Dabney, S.M., Liu, Z., Lame, M., Douglas, J., Zuu, J., Flanagan, D.C., 1999. Landscape benching from tillage erosion between grass hedges. J. Soil Till. Res. 51, 219-231.

De Alba, S., 1998a. Processes of soil degradation by erosion on agricultural lands in Mediterranean emvironments in Central Spain. Ph.D. Thesis. Universidad Autónoma de Madrid, 590 pp., unpublished (in Spanish).

De Alba, S., 1998b. Soil redistribution and erosion by tillage on steep agricultural lands. In: Gómez-Ortiz, A, Salvador-Franch, F. (Eds.), Recent Research on Spanish Geomorphology. Spanish Society of Geomorphology, pp. 471-482.

De Alba, S., 1999. A computer model for simulating soil redistribution and erosion by tillage operations using digital terrain models of arable fields. In: Proceedings of the Second Intemational Symposium on Tillage Erosion and Tillage translocation. Catholic University of Leuven, Belgium (abstract)

De Alba, S., 2001. Modelling the effects of complex topography and pattems of tillage on soil ranslocation by tillage with mouldboard plough. J. Soil Water Conserv. 56, 335-345.
De Alba, S., Lindstrom, M., 2000. Tillage erosion due to mouldboard ploughing: a computer model of simulation at field scale using DTMs. In: Proceedings of the Arumal Meeting of the ASA, SSSA and CSSA, Minneapolis, USA.

De Alba, S., Lindstrom, M., 2002. The effects of soil redistribution by tillage on soil spatial variability: towards a new conceptual model of soil catena evolution in agricultural landscapes. In: Proceedings of the Intemational Symposium on Sustainable Use and Management of Soils in Arid and Semiarid Regions, Polytechnic University of Cartagena, Spain.

FA 1988. FAO-UNESC Soil Map of the World, Revised Legend. World Soil Resources Report 60. Food and Agriculture Organization, Rome, Italy.

Govers, G., Vándaele, K., Desmet, P.J.J., Poesen, J., Bunte, K., 1994. The role of tillage in soil redistribution on hillslopes. Eur. J. Soil Sci. 45, 469-478.

Govers, G., Quine, T.A., Desmet, P.J.J., Walling, D.E., 1996. The relative contribution of soil tillage and overland flow erosion to soil redjstribution on agricultural land. Earth Surf. Process. Landfornns 21, 929-946.

Govers, G., Lobb, D., Qujne, T., 1999. Tillage erosion and ranslocation: emergence of a new paradigm in soil erosion research. J. Soil Till. Res. 51, 167-174.

Kosmas, C., Gerontidis, St., Marathianou, M., Detsis, B., Zafiriou, Th., Van Muysen, W., Govers, G., Quine, T.A., Van Oost, K., 2001. The effect of tillage displace soil on soil properties and wheat biomass. J. Soil Till. Res. 58, 31-44.

Lane, A. (Coordinator), 1997. Best Management Practices: Soil Management. Ministry of Agriculture, Food and Rural Affairs, Ontario, $68 \mathrm{pp}$.

Lindstrom, M.J., Nelson, W.W., Shumacher, T.E., Lenune, G.D., 1990. Soil movement by tillage as affected by slope. J. Soil Till. Res. 17, 255-264.

Lindstrom, M.J., Nelson, W.W., Shumacher, T.E., 1992. Quantifying tillage erosion rates due to moldboard plowing. J. Soil Till. Res. 24, 243-255.

Lindstrom, M.J., Shumacher, T.E., Malo, D.D., 2000. Soil quality alterations across a complex prairie landscape due to tillage erosion. In: Morrison, J.E., Chair, Jr. (Eds.), Proceedings of the 15th International Conference of the Intemational Soil Tillage Research Organization (ISTRO-2000).

Lobb, D.A., Kachanoski, R.G., 1999. Modelling tillage translocation using step, linear-platean and exponential functions. J. Soil Till. Res. 51, 317-330.

Lobb, D.A., Kachanoski, R.G., Miller, M.H., 1995. Tillage ranslocation and tillage erosion on shoulder slope landscape positions measured using Cs-137 as a tracer. Can. J. Soil Sci. 75, 211-218.

Mech, S.J., Free, G.R., 1942. Movement of soil during tillage operations. Agric. Eng. 23, 379-382.

Papendick, R.I., Miller, D.E., 1977. Conservation tillage in the Pacific Northwest. J. Soil Water Conserv. 32, 49-56.

Poesen, J.W., Van Wesemael, B., Govers, G., Martúnez-Fernández, J., Desmet, P., Vandaele, K., Quine, T.A., Degraer, G., 1997. Pattems of rock fragment cover generated by tillage erosion. Geomorphology 18, 183-197.

Qujne, T.A., Walling, D.E., Znang, X., 1993. The role of tillage in soil redistribution within terraced fields on the 
loess platean, China: an irrvestigation using caesium-137. In: Proceedings of the Warsaw Symposium on Runoff and Sediment Yield Modelling, Depantment of Hydraulic Structures, SGGV, September 1993, pp. 149-155.

Revel, J.C., Guiresse, M., Coste, N., Cavalie, J., Costes, J.L., 1993. Erosion hydrique et entrainement mécanique des teres par les outlis dans les côteaux de sud-ouest de la France. La nécesité d'établir un bilan avant toute mesure anti-érosive. In: Wicherek, S. (Ed.), Farm Land Erosion in Temperate Plains Emvironments and Hills. Elsevier, Amsterdarn, pp. 551-562 (in French).

Schmidt, B.L., Allmaras, R.R., Mammering, J.V., Papendick, R.I. (Eds.), 1982. Determinants of Soil Loss Tolerance. ASA Publication No. 45, p. 153

Schumacher, T.E., Lindstrom, M.J., Schumacher, J.A., Lenune, G.D., 1999. Modeling spatial variation in productivity due to tillage and water erosion. J. Soil Till. Res. 51, 331-339.

Sibbensen, E., Andersen, C.E., 1985. Soil movement in long-term field experiments as a result of cultivation. II. How to estimate the two-dimensional movement of substances accumulating in the soil. Exp. Agric. 21, 109-117.

Soil Survey Staff, 1990. Keys to Soil Taxonomy (4th edn.) Soil Management Support Services. US. Dept. Agric. Tech. Monograph No. 19
Torri, D., Borselli, L., 2002. Clod movement and tillage tool characteristics for modelling tillage erosion. J. Soil Water Conserv. 57, 24-28.

Torri, D., Borselli, L., Calzolari, C., Yañez, M., Salvador-Sanchis, M.P., 2002. Soil erosion, land use, soil quality and soil functions: effects of erosion. In: Rubio, J.L., Morgan, R.P.C., Asins, S., Andreu, V. (Eds.), Man and Soil at the Third Millennium. Geoforma Ediciones, CIDE, pp. 131-148.

Van Muysen, W., Govers, G., Bergkamp, G., Roxo, M., Poesen, J., 1999. Measurement and modelling of the effects of initial soil conditions and slope gradient on soil ranslocation by tillage. J. Soil Till. Res. 51, 303-316.

Van Muysen, W., Govers, G., Van Oost, K., 2002. Identification of important factors in the process of tillage erosion: the case of mouldboard tillage. J. Soil Till. Res. 65, 77-93.

Van Oost, K., Govers, G., 2000. WATEM, online manual. Catholic University of Leuven. http:/wwwkuleuven.ac.be/facdep/geo/ fgk/leg/pages/downloads/WaTEM/WatemHomehm.

Van Oost, K., Govers, G., Van Muysen, W., Quine, T.A., 2000. Modelling ranslocation and dispersion of soil constituents by tillage on sloping land. Soil Sci. Soc. Am. J. 64, 17331739. 